\title{
Dynamics of Muslimat Nahdlatul Ulama Under Mahmudah Mawardi Leadership In 1950-1979
}

\author{
Samsuniyah \\ UIN Sunan Kalijaga Yogyakarta \\ suniiab05@gmail.com
}

\begin{abstract}
This research discussed about Muslimat Nahdlatul Ulama (Muslimat NU) in 1950-1979 AD led by Mahmudah Mawardi. Muslimat NU at that time experienced a significant development than before. This article starts the discussion by providing the condition ofMuslimat Nahdlatul Ulama before the leadership of Mahmudah Mawardi, which were Chadidjah Dahlan period in 1946-1947 and Hindun period 1947-1950. Among the superior work program by Muslimat NU at that time was the eradication of illiteracy. In the social field, Muslimat NU established Muslimat NU Welfare Foundation that specifically handled Muslimat NU programs engaged in social affairs. When the government issued the Family Planning (KB) program, Muslimat NU gave a positive and active response in succeeding the program. In the field of politics, Muslimat NU participated in the struggle for the law on marriage that does not violate Islamic sharia and purposing to protect women. The results of this study explain that the Muslimat NU during Mahmudah Mawardi's leadership experienced rapid progress, thiswas supported by its members in developing the organization and the support of PBNU as its core organization.
\end{abstract}

Keywords: organization, leadership, muslimat nu, activity

\section{INTRODUCTION}

The 18th Muktamar Nahdlatul Ulama (NU) on April 28 to May 3, 1950 in Jakarta elected Mahmudah Mawardi as the third chairman of Muslimat NU, an autonomous body for Nahdlatul Ulama women, from 1950 to 1979. Hence Muslimat NU experienced significant development in its programs in the social, educational, and religious fields under her leadership from 1950 to 1979. During the period, members of Muslimat NU were actively involved in politics for the first timeby becoming members of the House of Representatives (DPR) and the 
Dynamics of Muslimat Nahdlatul Ulama Under Mahmudah Mawardi ... (Samsuniyah)

Regional People's Representative Council (DPRD), and numbers of Muslimat NU leaders sat in the Religious Court (Natsir, 1993). In the field of politics, during 1950s, Nahdlatul Ulama members were actively involved in promoting government policies related to women. In 1955, where NU actively engaged in general elections as political party, NU gained significant number of $18.4 \%$ of all votes. The result increased NU representatives in parliament, from 8 seats (when joined under Masyumi) to 45 seats (after NU becoming political party) (Bruinessen, 1994).This makes Muslimat NU members earned 5 representatives $(10 \%)$ which was a large portion compared to other parties. Meanwhile there were five Muslimat NU figures who sat in the House of Representatives; Mahmudah Mawardi (Central Java), Maryam Kantasumpena (Central Java), Maryam Djunaidi (East Java), Hadiniyah Hadi (EastJava) and Asmah Syahruni (South Kalimantan).

Muslimat NU gave a positive response when the government initiated a Family Planning (Keluarga Berencana, known as KB) program in 1968. The Indonesian government realized the role of NU members whose existence mostly spread in rural area and have large number of women. This made Muslimat NU involved in the National Family Planning Agency (LKBN) which later changed to the National Family Planning Coordinating Agency (BKKBN). Muslimat NU was then represented by Hj. Sholihah Wahid Hasjim and Chasanah Mansyur (Ma'sum, 1973). Then in 1973, Muslimat NU began to form a KB project for their own members. These projects were led by Solechah Saifuddin Zuhri (1974-1975), Fahmi D. Saifuddin (1975-1976), and Mrs. Soeparman (1976-1977). The activities carried out by the project are such as the orientation of $\mathrm{KB}$ in some areas that are considered vulnerable in the implementation of $\mathrm{KB}$ programs, socializing $K B$, population and birth control education seminars, counseling and motivation for birth control among adolescents, and the preparation of a book with the title "Fostering Family Benefit".

Other Muslimat NU programs such as: participating in the Marriage and Divorce Settlement Advisory Board (BP4) in 1952, establishing and developing the Muslimat NU Welfare Foundation in 1962. Actively involved in the holding of the 1964 Asian-African Islamic Conference in Bandung, (Natsir, 1993) joined the Indonesian Women's Congress (KOWANI) in 1956 (Suryochondro, 1984), 
JNUS: Journal of Nahdlatul Ulama Studies, Vol. 2, No. 2, Juli 2021: 138-150

participated in the establishment of the Indonesian Women's Islamic Organization (BMOIWI) Deliberation Board in 1967, and was actively involved in the National Committee for the Position of Indonesian Women (KNKWI) in 1968. Not only that, Muslimat NU has extra activities for its useful members such as volunteer training in 1964, military training, organizing in public kitchens, First Aid Lessons (PPPK), overcoming fire hazards, and so on.

Seeing such development of activities carried out by NU members during 1950-1979in various fields, researcher is interested to analyze the development during the period. Muslimat NU, as representative of women in the largest Muslim organizations in Indonesia, actively initiated a movement that have a positive influence, especially on women. Such initiatives empower women, participating in including women into social and public social intiatives.

Muslimat NU during 1950-1979 period was able to push progression among Muslim women, so it is interesting to write. Writing about the history of the women's movement has been done a lot, but the history of women movement is still left behind in social sciences (Kuntowijoyo, 2003). Although women are featured in history, they are nothing more than complementary. The study of the history of Muslimat NU is purposed to contribute in the writing of the history of the women's movement. Therefore, the author is interested in conducting a study of the study explicitly, implicitly, andexplanatory under two academic problems; First, what was the condition and situation of Muslimat NU before the leadership of Mahmudah Mawardi? Secondly, how did the development and significance of Muslimat NU during the leadership of Mahmudah Mawardi?

\section{THEORIES AND METHODOLOGY}

Historical analysis in this study uses a sociological approach. History is intended asan attempt at understanding and explaining social behaviors. This behavior is related to the efforts made by a movement. The theory used is the theory of structural-functional theory put forward by Talcott Parsons. Structuralfunctional theory recognizes all diversity in social life. Diversity in this case is the main sourceof the structure of society and determines the diversity of functions according to one's position in the structure of a system. These different functions aim to achieveorganizational goals, not for the benefit of individuals. This theory has four functional imperatives for the system. To survive a system must carry out the four functions, namely adaptation, achievement of goals, integration, and latency (Marzuki, 2007). 
The method used in this study of historical research methods applied follows the steps taken by Louis Gottschalk. The four stages are: first, heuristic (source gathering) sources used are written and unwritten sources or oral sources. Primarysources in the form of documented archives of congressional results, results of NU conferences, and photographs of NU Muslimat activities in 1950-1979 AD, while secondary sources in the form of books, thesis, journals, Articles, and so on. Researchers alsoconducted interviews with Mahmudah Mawardi's children Farida Purnomo, Latifah Hashim, and Niswah who is Mahmudah's cousin, this is to find out the figure of Mahmudah. Second, verify by testing and critically analyzing data both external and internal to the sources obtained, both from journals, books, interview results, thesis, and others. Third, the interpretation of researchers interprets the facts that have been obtained related to the activities carried out by NU Muslims based on sources. The last

\section{DISCUSSION}

\section{Muslimat NU under Leadership of Chadidjah Dahlan (1946-1947)}

At the time of the 16th Mu'tamar Nahdlatul Ulama (NU) precisely on March 29, 1946, in Purwokerto, officially confirmed the birth of Muslimat Nahdlatul Ulama (Muslimat NU) as a women's autonomous body under NU. This is at the effort of Mohammad Dahlan by making some kind of statement of acceptance of NU Muslims and signed by K.H. Hasyim Asy'ari and K.H. Abdul Wahab Hasbullah. (NU, 1946) The aim is to awaken Indonesian Islamic women to their obligations tobe true mothers so that they can strengthen and help NU's work in upholding the religion of Islam (Ma'sum, 1973). On March 29, 1946, Chadidjah Dahlan was elected as the first chairman of the Muslimat NU Central Leadership after Muslimat was recognized as part of NU.

Chadidjah Dahlan was born in Pasuruan, East Java in 1912. (Mulyati, 2017). She lives in a predominantly Muslim students' environment (santri) and a very fanatical society. Chadidjah grew up as a free and advanced child. Looking at the conditions faced by women at that time according to him there was injustice and undue treatment experienced by women (Anam, 2014). People may recognize Djuaesiah as the firstwoman to rise in the pulpit before the Muslimat NU was inaugurated, then Chadidjah Dahlan is the first Muslimat NU figure to give an official speech since Muslimat became the organization at the first congress in Purwokerto. During her leadership, she focused on strengthening the Muslimat NU movement itself by making membership marks, symbols, and subsequent work programs. 
JNUS: Journal of Nahdlatul Ulama Studies, Vol. 2, No. 2, Juli 2021: 138-150

\section{Muslimat NU under Leadership of Hindun (1947-1950)}

Muslimat NU experienced a power vacuum after Chadidjah Dahlan passed away so that central board of NU held a meeting to determine the interim chairman. This is in accordance with the special regulations of article 8 so that the work program that has been planned can be smoothly pursued. Hindun was elected interim chairman in 1947. At this time it has developed with 9 branches of Muslimat NU in Madiun, Surabaya, Banyumas, Cirebon, Priangan, Malang, Tapanuli, Jember and Kedu.

Muslimat NU during Hindun's leadership continued the previous work program, one of which is to eradicate illiteracy among women. This aims to advance women in educating their children, but then the work program does not run smoothly due to limited numbers of human resources. Until the holding of Muslimat NU membership cadre courses was attended by 80 people. The speakers were K.H. Abdul Wahab Hasbullah, K.H. Mohammad Dahlan and K.H. Saifudin Zuhri. (Mulyati, 2017).

\section{Mahmudah Mawardi, Eight Times Leader of Muslimat NU}

Mahmudah Mawardi was born in East Keprabon, Solo on 12 February 1912. (Ma'sum, 1973). He was the daughter of Kyai Masjhud and Maemunah. Her father was one of the pioneering figures of the establishment of NU in Solo and the caretaker of pesantren Al-Masjhudiyah. Mahmudah studied at Madrasah Ibtidaiyyah Sunniyah in Keprabon, Solo and graduated in 1923. After that, she studied at Madrasah Tsanawiyyah Sunniyah for 3 years. She also served as a santri in Pesantren Jemsaren Solo under guidance of K.H. Mohammad Idris. Mahmudah was a learned santri, pious, and memorizer of the Qur'an. (Niswah, 2018).

Mahmudah married Mawardi, so her name followed her husband's name as Mahmudah Mawardi. Mahmudah used her husband's name for her last name because at the time, some of the wives who were active in Muslimat NU, took their own husband's name for her last name. Mawardi is a respected PSII movement figure in Solo. Mawardi also introduced Mahmudah about the national movements. Mahmudah was interested in following him. Mahmudah was one of the founders ofthe Muslim women's organization in Solo, Nahdlatul Muslimat (NDM) in 1933. The goal is to advance women, especially in the field of education. She is also activein several organizations such as the Federation of Islamic Women in Solo (Surakarta Islamic Women's Union), the Central 
Dynamics of Muslimat Nahdlatul Ulama Under Mahmudah Mawardi ... (Samsuniyah)

Indonesian National Committee inYogyakarta, the Indonesian Muslim League, the Indonesian National Front in Jakarta, and the Indonesian National Committee.

During the war of the Republic of Indonesia against the Netherlands in 1945, Mahmudah joined the ranks of Hizbullah or Sabilillah in Surakarta on October 12, 1945 to September 19, 1947. She helped in providing open kitchen and collect medicines with other women to meet the needs of Indonesian freedom fighters (Mulyati, 2017).In 1946, Mahmudah was elected to the Surakarta City Parliament from the women's representatives. At the same time, she was also elected as a member of BP KNPI representing Masyumi who at that time Nahdlatul Ulama was still joining Masyumi. Continuingduring the reign of RIS, she sat as a member of the RIS Parliament in Yogyakarta in1959.

\section{Development of Muslimat NU during Leadership of Mahmudah Mawardi (1950-1979)}

Mahmudah Mawardi served as chairman of Muslimat NU for eight periods or 29 years,from 1950 to 1979 . Mahmudah was elected during the $3^{\text {rd }}$ Muslimat congress and coincided with the $18^{\text {th }}$ Muktamar NU. Mahmudah Mawardi's involvement in Muslimat NU occurred when she met and befriended Chadidjah Dahlan in Sarekat Islam Putih with her husband. Chadidjah Dahlan, who was then close to A. Mawardi, then asked Mahmudah to replace him as general chairman of Muslimat NU because she often got health problem and she decided to rest at home.

The $18^{\text {th }}$ Muktamar NU occurred in Jakarta from 31 April to 3May 1950 which coincided with the $3^{\text {rd }}$ Muslimat congress, where Mahmudah Mawardi was elected as chairman of Muslimat NU. The main reason for her being selected as chairman is because of the mandate of Chadidjah Dahlan. In addition, Mahmudah has been active in Muslimat NU to succeed the programs planned by Muslimat NU. Beforehand, Muslimat NU was named NUM (Nahdlatul Ulama Muslimat) then 1952 changed to Muslimat NU because it was inaugurated into an autonomous body under NU.

Mahmudah Mawardi was elected for eight terms in two ways, namely appointed with the support of the central board of NU (PBNU) and all members of the Muslimat NU and elected by voting. She was directly appointed four times in four congress (1950,1952, 1959, and 1962) and elected twice by vote (1954 and 1967). 
JNUS: Journal of Nahdlatul Ulama Studies, Vol. 2, No. 2, Juli 2021: 138-150

\section{Development in Education Field}

After Muslimat NU officially approved as autonomous body under NU, the first program is development in education, to increase the intelligence of women about the teachings of Islam. Interms of education does not mean that Muslimat competing with LP Ma'arif NU, which is managing education institutions under NU. But Muslimat NU is more focused on children education, especially seeking to get a official decree from LP Ma'arif NU to manage Kindergarten School (STK (Anam, 2014). Muslimat NU Kindergarten School in its handlers does not always run smoothly. The existence of challenges for educators so that education is opened for prospective STK educators under the name of Kindergarten Teacher School (Purnomo, 2018).

Muslimat NU not only conducts formal education but also by holding non-formal education. This is related to Muslimat NU program, namely the eradication of illiteracy. Another education is the existence of skills courses held by Muslimat NU. As for the skills are such as how to cut fabric to be used as clothes,pants and any kind of necessities, how to sew the fabric that has been cut, arrange dry flowers and janur, cook and make up for the bride. The existence of the course is expected that theparticipants will be able to try it themselves and be productive so they can earn livelihood for daily needs.

In 1977 Muslimat NU held a population education training program of NahdlatulUlama school core officials in Java and Bali. The training is held because it is part of the Family Planning program with the theme "National Program" which has been pursued by the government as an effort to overcome population problems with various implications of the crisis and other possible consequences (Muslimat, 1977).

\section{Religious Field}

Muslimat Nahdlatul Ulama (NU) at the beginning of its establishment already hada view on the insight of Islamic ukhumwah. At the beginning of Mahmudah Mawardi's leadership in 1950, Muslimat NU tried to direct the efforts of amar ma'ruf nahi munkar (Enjoining what is right and forbidding what is wrong). Therefore, the form of various activities circle of studies, majlis taklim, lectures, seminars, or publishing books. Muslimat NU in the field of religion is a fairly popular activity. Some are done by NU Muslims as a movementof women under the leadership of NU board in the religious field to help and make easire NU duties. 
The study conducted by Muslimat NU is usually related to the themes of how a woman can become a mother under concept sholihatun khamilatun, namely by explaining thecontent of the meaning of the Qur'an god's command to perform prayers, the importance of fostering harmony between religious people. Studies are divided into two, namely routine studies and general studies. Routine studies means that Muslimat NU organized at the Central Office of Muslimat NU to the territory of Muslimat NU branch which is followed by the board, majlis taklim and community citizens circles. Public studies are conducted in the open that can be attended by the general public. It does in every region, branches and branches. As for the time that is mostly implemented to coincide with Islamic holiday commemorations such as Maulid Nabi Mubammad, Isra' Mi'raj, Halal bi halal, and so on.

Muslimat NU also contributes ini the issue of marriage. Muslimat NU's concern for the issue of marriage at that time was really high. This is proven by its involvement in the Marriage and Divorce Settlement Advisory Board (BP4). Mahmudah Mawardi who at that time became the general chairman of Muslimat NU became one of the pioneers of the establishment of the body along with Mrs. Pudjo Utomo and Nasruddin Latief.

\section{Social Field}

Muslimat NU's effort and struggle to handle specifically in the social field was proven by establishing a foundation called Yayasan Kesejahteraan Muslimat (YKM NU) established on June 11, 1963. The foundation is to handle social charities such as Maternity Homes or BKIA and orphanages (Zuhri, 1973). YKM NU provides assistance in the form of tuition andtextbooks and clothing to a number of orphans. In 1966 Muslimat NU established a Muslim Maternity House located on Jalan Hang Tuan 1 No. 12 Kebayoran Baru,South Jakarta. Another Muslimat NU Maternity House (Rumah Bersalin, abbreviated as RB) is in the Rawangmangun area precisely the Street Ceiling No. 6 Kampung Ambon Rawangmangun, East Jakarta, which was established in 1968. The maternity house is then built in some areas by providing guidance and training skills. Its development in several areas such as West Aceh, Medan, Kudus, Purworejo, Sokaraja/Banyumas, Pekalongan,Yogyakarta, Ponorogo, Sidoarjo, Bangil, Pasuruan, Malang and Jombang.

During family planning (KB) program, Mahmudah Mawardi played a role as a representative of Muslimat NU who was active in meetings with other organizations to discuss the implementation of $\mathrm{KB}$ to be accepted by the 
JNUS: Journal of Nahdlatul Ulama Studies, Vol. 2, No. 2, Juli 2021: 138-150

community. This program did not run smoothly due to the cultural and mental barriers of the community. People still consider this program as an anti-birth program that in the view of society means rejecting God's destiny. In terms of the medical process and from the point of fear of poverty is also considered contrary to the teachings of Islam (Mulyati, 2016). The rejection of the community to the $\mathrm{KB}$ program is actually not due to technical factors, such as the wrong way of approach or the existence of an element of coercion for family planning and birth control.

Considering such problems and barriers, Muslimat NU was struggling to make $\mathrm{KB}$ to be well received by the Muslim community, by trying to ask for legal opinions from PBNU on the subject of KB. Therefore, on 25 September 1969, PBNU issued a fatwa (Islamic legal opinion) containing eight main guidelines on birth control that have long been awaited by Muslims, especially for NU members who are mostly Ablusunah wal Jamaah. With the fatwa, the areas that initially did not accept KB officers such as Madura, Banten,and the eastern end of Java Island are beginning to follow the KB program. In 1972 the orientation of Family Planning by NU Muslims has spread throughout the islands of Java and Madura.

Muslimat NU under Mahmudah Mawardi joined other women's movement organizations such as the Indonesian Women's Congress (KOWANI) which is a federation of national women's organizations. This is in carrying out work programs related to the social field. In addition, she is also an active member of the Indonesian National Committee of Women's Population (KNKWI) which is a body tasked with researching the position of women formed by the government in 1968. In 1967 Muslimat NU along with other women's movements established the Indonesian Women's Islamic Organization (BMOIWI) Deliberation Board in collaboration with the Ministry of Religious Affairs, the Ministry of Social Affairs and the Indonesian Ulema Council.

\section{Political Field}

Muslimat NU under Mahmudah Mawardi leadership was heavily involved in the field of politics. The involvement of NU members was pioneered by Mahmudah Mawardi when NU was still joining the Masyumi Party (1945). Mahmudah was appointed as a member of the Central Indonesian National Committee (BP KNIP). At the $18^{\text {th }}$ NU Conference in 1950, NU decided to withdraw themselves from Masyumi, this is because NU experienced 
disappointment one of them is Masyumi more concerned with the people outside special members who at that time NU became special members (Fathoni, 1992). At the time of the $19^{\text {th }}$ NU Muktamar in Palembang in 1952, NU then decided to completely quit Masyumi (Expres, 1952).

NU at the time was preparing to contest the 1955 elections. In this case, Muslimat NU as an autonomous body under NU began to be involved in politics. Women in politics have a very strategic position if women are able to manage the various potentials they have so that women's positions will be able to influence policy over political injustice on women (Ridjal, 1993). The involvement Muslimat NU in the NU political campaign was greatly appreciated. Not only because of his success when conducting the campaign that is applied but the struggle to get thingsas a candidate to be chosen. Although previously received a rejection from the NUside but then finally after a long debate, PBNU instructed Lajnah LAPUNU (Lajnah Pemilihan Umum NU, or Department for General Election Issues) to include people from Muslimat NU in the list of candidates. The campaigns carried out by Muslimat NU were effectively managed. They give more attention to the implementation of campaigns by word of mouth through charitable activities. In addition, Muslimat NU also utilizes mass media, namely Duta Masyarakat (1954).

The 1955 election was the first since Indonesia gained independence in 1945. The results of the election displayed four superior parties, namely: PNI (22.3\%), Masyumi(20.9\%), NU (28.4\%), and PKI (26.4\%). 192 With the result, Muslimat NU obtained 5 women as representatives of NU in parliament, PNI with 5 women, Masyumi with 3 women, and PKI with 5 women. The 5 women from Muslimat NUas representatives of the NU party are Mahmudah Mawardi, Maryam Kantasumpena, Maryam Djunaidi, Hadiniyah Hadi, and Asmah Syahruni.

At a time when NU were actively engage in politics, NU members struggled to register the Marriage Law. Women's anxiety was triggered because they consider the marriage rules used at that time are very detrimental to women. Referring to Instruction No. 4 of 1947 by the Minister of Religious Affairs, which contains aboutstill allowing the marriage of underage women and the practice of polygamy. The instruction was responded to by women, especially Muslimat NU (Zuhri, 1973). In 1950 a commission was formed that specifically designed marriage law or betterknown as the Nikah, Talak and Rujuk Commission (NTR Commission). They made and proposed the Marriage Bill so as not to harm women. Through a process, debate, and consideration that was long and long 
JNUS: Journal of Nahdlatul Ulama Studies, Vol. 2, No. 2, Juli 2021: 138-150

enough then in 1971 the Marriage Bill was submitted back to the government. Among women's organizations there are pros and cons. In 13 July 1973, finally, the government can prepare a new Marriage Bill, then submit it to the parliament, which consists of 15 chapters and 73 articles. On 2 January 1974 the Bill on marriage that has been approved by the House of Representatives was passed and enacted into Law No. 1 of 1974 on Marriage and effective on October 1, 1975, in this case, the Law has special characteristics, when compared to the previous law that is related to the principle, purpose and nature that raises the dignity and degree of women (Ali, 1995).

\section{CONCLUSION}

Muslimat NU is an officially autonomous body under NU which first led by Chadidjah Dahlan. Precisely at the time of the $16^{\text {th }}$ NU Conference on 29 March 1946 in Purwokerto, Chadidjah Dahlan was elected as the first chairman of the Muslimat NU after Muslimat NU was officially recognized by PBNU. Chadidjah is the first Muslimat NU to give an official speech since Muslimat NU became an organization in congress. During his leadership, Muslimat NU focused on eradicating illiteracy.

Muslimat NU during the Hindun leadership was a very short time. It is also because Hindun was appointed as interim chairman only to replace Chadidjah Dahlan who was sick and later passed away so that it reached the $18^{\text {th }}$ Muktamar NU to coincide with the $3^{\text {rd }}$ Muslimat NU congress electing Mahmudah Mawardi as thegeneral chairman of Muslimat NU. She led for eight periods precisely from 1950 to 1979.

Muslimat NU during her leadership experienced a rapid development than before. The activities carried out by Muslimat NU were meant to foster Muslim women's prosperty. Some of the areas that have been carried out by NU's Muslims are religious, educational, social, and political fields. In the field of religion, Muslimat NU conducts severalactivities such as studies that are divided into two, namely routine studies carried out by loyal members of Muslimat NU the second is general recitation for public.

In the field of education, Muslimat NU has several work programs that they provide, such as the creation of a school for children called the Kindergarten School. With the existence of the school, Muslimat NU also formed the Muslimat NU Kindergarten Teacher Association. Not only formal education, but Muslimat NU also held a non-formal school, namely by encouraging mothers to preach and eradicating illiteracy. Another education is by holding skills courses. 
The social field has progress comparable to other fields. On 11 June 1963 , Muslimat NU established the Muslimat NU Welfare Foundation (YKM NU) which is tasked for maintaining the welfare of women, especially members of Muslimat NU. When the government issued the Family Planning (KB) program, Muslimat NU was also active in succeeding the programs. When NU members participated in politics, it is highly utilized by Muslimat NU. In this case, is to manage the various potentials that women have, so that the position of women will affect the state policy regarding political injustice among women. While activein politics, Muslimat NU along with other women from several factions urged the government to pass Marriage Law which was very crucial.

\section{REFERENCES}

Aisyah Dahlan. (1955) Sejarah Labirnya Muslimat Nabdlatul Ulama di Indonesia. Jakarta: P. P. Muslimat NU.

Album Foto Mu'tamar Nahdlatul Ulama ke-19 pada tanggal 26-30 April tahun 1952 di Palembang yang dihimpun oleh bagian dakwah PBNU.

Buku petunjuk Mu'tamar Nahdlatul Ulama ke-24 bertepatan dengan kongres Muslimat NU ke-9 pada 4 sampai 9 Juli 1967 di Bandung.

Hasil Mu'tamar Nahdlatul Ulama ke-22 tanggal 13-18 Desember 1959 di Jakarta. Koleksi foto perpustakaan PBNU mengenai Mu'tamar Nahdlatul Ulama ke-25 bertepatan dengan kongres Muslimat NU yang ke-10 pada tanggal 5 sampai 11 Juni 1979.

Ma'shum, Saifullah dan Ali Zawawi, dkk., (1996). editor. 50 Tabun Muslimat NU Berkbidmat untuk. Agama, Negara dan Bangsa. Jakarta: P. P. Muslimat NU.

Marcoes- Natsi, Lies M, dkk. (1993) Wanita Islam Indonesia dalam Kajian Tekstual dan Konstektual. Jakarta: INIS.

Mulyati, Sri., dkk (2016). 70 Tabun Muslimat NU Kiprah \& Karya Perempuan NU. Jakarta: P. P. Muslimat NU.

Mustafa Helmi. (2002) Asmah Syachruni Muslimah Pejuang Lintas Zaman. Jakarta: Pustaka Indonesia Satu.

P.P Muslimat NU. (1977). Laporan pelaksanaan Keluarga Berencana (KB) dan Pembentukan L. K. K. yang dibuat oleh Yayasan Kesejahteraan Muslimat Pusat di Jakarta pada 9 November.

P.P Muslimat NU. Pedoman pelaksanaan program latihan pendidikan kependudukan pejabat teras sekolah Nahdlatul Ulama se-Jawa dan Bali. Poetoesan ${ }^{2}$ Moe'tamar Nahdlatul Ulama yang ke-16 tanggal 26-29 Maret 1946 di Purwokerto. 
JNUS: Journal of Nahdlatul Ulama Studies, Vol. 2, No. 2, Juli 2021: 138-150

Ridjal, Fauzie., dkk. (1993). Dinamika Gerakan Perempuan di Indonesia. Yogyakarta: Tiara Wacana.

Surat Kabar EXPRES diterbitkan pada tanggal 5 dan 8 Mei 1952.

Suparman, Ny., dkk. (1977). Membina Kemaslahatan Keluarga: Pedoman Pelaksanaan Program Keluarga Berencana dan Pendidikan Kependudukan. Jakarta: Yayasan Kesejahteraan Muslimat NU.

Suryochondro, Sukanti. (1984). Potret Pergerakan Wanita di Indonesia. Jakarta: Rajawali.

Syaifullah, Gerakan Politik Muhammadiyah dalam Masyumi. Jakarta: Pustaka Utama Grafiti, 1997.

Wilar, Abraham Silo. Penghancuran Gerakan Perempuan: Politik dan Pemikiran Kaum Perempuan NU. Jakarta: Pyramida Media Utama, 2009.

Wawancara dengan Farida purnomo sebagai anak ketiga dari Mahmudah Mawardi tanggal 13 Januari 2018 di rumah ibu Farida Jalan Kebon Sirih Barat No. 07, Jakarta Pusat.

Wawancara dengan Niswah sebagai keponakan dari Mahmudah Mawardi tanggal 30 November 2017 dan 9 April 2018 via telepon di Yogyakarta.

Yayasan Kesejahteraan Muslimat Pusat. (1977). Pedoman Pelaksanaan Program Latihan Pendidikan Kependudukan Pejabat Teras Sekolah Nahdlatul Ulama Se-Jawa dan Bali. Jakarta.

Zuhri, Ny. Saifuddin. (1973). Sejarah Muslimat Nabdlatul Ulama. Jakarta: P. P. Muslimat NU Jakarta. 